\title{
CANIBAL LECTOR: DA LEITURA E TAREFA DO NARRADOR COMO DEGLUTIÇÃO DIABÓLICA
}

\author{
Pedro Serra \\ (Universidade de Salamanca)
}

\section{RESUMO}

"Os Canibais", conto de Álvaro do Carvalhal, lido como alegoria da tensão entre demos e daemon no âmago do social.

PALAVRAS-CHAVE: escrita e leitura; banquete canibal; riso diabólico.

\section{ABSTRACT}

"Os Canibais", written by Álvaro do Carvalhal, read as an allegory of the tension between demos and daemon at the core of society.

KEYWORDS: writing and Reading; canibal banquet; diabolic laughter. 
"Ah! chers amis, ne lisez pas Brillat-Savarin.

Dieu préserve ceux qu'il chérit des lectures inutiles"

Baudelaire (1975, p. 378)

O riso do narrador d' “Os canibais" (1866), conto 'frenético' de Álvaro do Carvalhal (cf. 1990) ${ }^{1}$, não parece ser comunal, nem gerar comunidade. A origem dessa voz crítica é, no mínimo, difícil de identificar. Crítica que não provém de uma consciência pequeno-burguesa, o narrador ridente não parece representar tal consciência. É, o seu, um riso luciferino, tensado entre a "miopia burguesa" e o amor pelo "sangue azul", polaridades que fissuram a possibilidade de um qualquer lugar autoconsciente imune a essa mesma derrisão (isto é, um lugar que supere o lugar polarizado de onde fala): o conto não resolve contradições, radicaliza-as. Creio, entretanto, que o conhecido filme de Manuel de Oliveira responde precisamente a esta percepção, resolvendo-a em parte ao desdobrar a figura do narrador nas personagens do apresentador e de Nicoló, o violinista. Nicoló Paganini, violinista do diabo, precisamente. Significativa, neste sentido, a explosão final de Nicoló - 'estala', como a figura luciferina de muitas literaturas antecessoras - e a sua subsequente substituição pelo magistrado-porco. Veja-se como o filme distingue os subalternos das classes elegantes, os primeiros 'falam', os segundos 'cantam'. Mas o final é o de um baile comum, e a transfiguração canibal manifiesta-se em todas as personagens, amos e criados. $\mathrm{O}$ mundo social $v \hat{e}-s e$ a si mesmo, deste modo, numa nova "enorme fealdade". Fealdade mundana, isto é, diabólica. No conto, a figura do canibal perfaz uma versão do 'inimigo da geração humana': o 'outro' da sociedade que, paradoxalmente, possibilita a conformação do socius. Demos e daemon, como já foi notado, provêm de uma mesma raiz etimológica.

Vejamos como a fábula ajuda a descrever esta figura da "enorme fealdade", ao mesmo tempo que ela, fábula, é proposta como uma sua amostra. Assim, o corpo protético do Visconde de Aveleda, protagonista byroniano do inquietante conto, é tanto coisa como casulo de ser que ainda se imagina apessoado. É corpo sanguíneo, e como tal, carniforme; mas é também um corpo maquilhado. $\mathrm{O}$ tronco será justamente carne própria para consumo. O corpo protético, por seu turno, tem nas mãos de marfim ocultadas por luvas brancas o seu lugar mais expressivo. É um corpo equívoco: tomado por pessoa quando é coisa; e por coisa sendo pessoa. Um corpo entre o 'vermelho' da sua condição sanguínea, o 'branco' da sua condição artificial e o 'ouro' que lhe circula nas veias. Este espectro cromático é próprio de um atributo espectral: o "sangue azul". "Os Canibais", alegoria de um corpo político vitimizado pela História - a aristocracia titular de um D. João, adventícia no que toca ao Visconde de Aveleda com fortuna amassada no Império (veio da "América") -, declara-se conto "amador de sangue azul" (CARVALHAL, 1990, p. 208). Um fantasma percorre este conto: o fantasma da aristocracia, que não obstante se vai impondo com 
contumácia numa sociedade burguesa - "civilizada" e "liberal" - que se imagina anacronicamente "raça gótica". Aristocracia que ora "fascina", ora se mostra "ardente" e "melancólica", consabidos atributos do herói satânico romântico, como exemplarmente estudou Mario Praz em La carne, la morte e il diavolo. (1999, pp. 115 e ss.).

Assim, o sujeito gótico perde o privilégio - a propriedade, o próprio que o define - do sangue. D. João, por exemplo, é o último dos filhos únicos da aristocracia, e consequentemente da economia política, moral e cultural que a sustenta. O Visconde de Aveleda, por seu turno, expõe a expropriação do indivíduo de um específico que lhe permita ser quem é - que é justamente o que o Visconde não pode ser. Aveleda nivela um "visconde" e uma carne "viscosa", a crer nos comensais que acabarão por reconhecer ter sido partícipes de um festim antropófago. A simbólica do "sangue" é comutada por uma banalização do sujeito humano: o conto encontrará o mínimo denominador comum do indivíduo e da comunidade, em tempos da civilização e do liberalismo, na figura do canibal. É a figura de uma moral contrafeita: já só há comer e ser comido e algo como um movimento autónomo do dinheiro. O capital do Visconde de Aveleda não é legado pelo sangue - a nupcialidade, alienada, não produz descendência; é independente desse modo de legar. A herança é coisa de uma magistratura providencial - de um Estado que legifera direitos 'universais' -, isto é, que salva.

Carvalhal é desconstrutor de mitos: nesta ocasião é-o sobretudo no que diz respeito ao mito de Pigmalião. Recordemos que o narrador quer ser guia espiritual das jovens donzelas que se deixam 'cegar' por figuras como a de D. João ou do Visconde de Aveleda. Esta cruzada visa expor um modo de produzir verdade, uma verdade falsa, ou que se procura mostrar como sendo falsa. O mito ovidiano, objectivando um 'novo' tipo de apaixonado, devolve também uma espécie peculiar de artista: “Tal era o poder deste jovem esquivo - estava na posse da suprema realização artística, a arte que oculta a arte" (HAMILTON, 1991, p. 155). Uma arte que oculte a arte é uma arte naturalizada que pode comutar-se com a 'vida'. Daí a paixão do artista por uma estátua. Ora, "Os Canibais" propõe um percurso inverso: a Margarida são-lhe revelados os mecanismos que contrafaziam a vida numa estátua. O sujeito bem apessoado é apenas uma coisa. E como tal é consumido pelo pai e pelos irmãos da jovem.

Ora, o narrador, enquanto se diz capacitado para a crítica de uma sociedade que literaliza os seus discursos figurados, que vive a vida como metáfora (MILLER, 1982, p. 13), não pode, entretanto, não ter o seu quê de moralizador. Os dois lugares do relato em que essa tópica moral é enunciada são os seguintes: a "aparência - diz-nos - nivela vício e virtude" (CARVALHAL, 1990, p. 237); ou, ainda, "crimes não os vê a sociedade, e se os vê, respeita-os" (CARVALHAL, 1990, p. 238). O Visconde de Aveleda é, por um lado, o revenant de Pigmalião. Mas é também, e aqui acompanha-o D. João, o revenant da "raça gótica" de "sangue azul". Neste sentido, o relato de "Os Canibais” é um relato histórico, pois representa a dessimbolização da 
aristocracia no palco da História. É fantasma de uma temporalidade com que se não conjuga, uma temporalidade fora dos gonzos. Note-se que é enquanto relato histórico que o conto é também sensível ao presente e aos costumes, ou à analítica dos costumes. A sensibilidade ao presente implica sabê-lo saturado de História.

Não se trata apenas, por conseguinte, de uma crítica literária de gostos literários. Não apenas, mas também o é, como tem vindo a ser notado. Veja-se, por exemplo, a seguinte formulação: "O autor faz uso da função pedagógica da literatura, criticando não só os vícios da sociedade como também os modelos literários da época" (SANTOS, 1997, p. 77, col. 2). O que porventura excede esta acertada asserção é que o conto nos propõe um social que se indistingue do literário. Numa outra leitura, entretanto, ficam patentes os limites de uma descrição de Carvalhal como crítico de um programa literário (e que, como tal crítica, dele se pudesse destacar, o que de resto sabemos que não faz): diz-se, assim, que "n'Os Canibais [Carvalhal faz] a caricatura do programa ultra-romântico, sem dele tomar a devida distância, como Novais, Camilo e multidão dispersa por álbuns e almanaques, traço reflexivo, esse, de continuidade moderna" (RODRIGUES, 1997, p. 566, cols. 1-2). O problema, nesta formulação, está no supor uma "devida distância” que fizesse da reflexividade uma reflexividade "moderna". Na verdade, penso que o narrador se instala na aporética que alia inextricavelmente "miopia burguesa" (CARVALHAL, 1990, p. 219) e "adora[ção da] aristocracia” (CARVALHAL, 1990, p. 208), aliança sustentada por algo como uma cultura ultra-romântica. Como argumentarei, o narrador é um moralista cujo modo de representar uma moral passa pela apresentação de uma moralidade contrafeita: o canibalismo como próprio dos indivíduos civilizados. O canibalismo é a monstruosidade moral que organiza a vida social à custa dos sujeitos. Em última instância, o que se argumenta é que os indivíduos são canibalizados pelo canibalismo. No corpo individual e no corpo social há um líquido mais vital que o "sangue azul", e que o subsume: o capital. Como diz uma personagem a páginas tantas, vive-se pelo ouro. Tudo somado, a tarefa do narrador não pode deixar de ser parti pris do Diabo.

Avanço agora pelo lugar do acontecimento canibal - figura da "enorme fealdade", figura, enfim, satânica - nas leituras críticas deste conto 'frenético'. Por norma, são leituras que articulam fórmulas que, de algum modo, obviam a comensalidade antropofágica. Ou melhor, são leituras que acolhem incomodamente a canibalização do visconde de Aveleda. Vale a pena recordar o capítulo dedicado a Álvaro do Carvalhal por João Gaspar Simões na sua Perspectiva Histórica da Ficção Portuguesa (1987). Apenas um punhado de parágrafos, pouco mais do que um par de páginas. E contudo, do meu ponto de vista, com intuições relevantes para a ponderação do corpus narrativo de Carvalhal (1844-1868), um autor nas margens do cânone da prosa de ficção portuguesa do século XIX; ou, diria ainda, um caminho truncado que só uma história contrafactual pode retomar. E, con- 
tudo, Simões urde a sua valoração estética e histórico-literária do autor do conto "Os canibais" configurando para ele um lugar de absoluta singularidade: "Seja como for, o caso de Álvaro do Carvalhal representa algo único na história da evolução do conto português do século XIX” SIMÕES, 1987, p. 563). Carvalhal, formulado nestes termos, é único, a sua escassa produção escrita - obra e vida breves (morreu de um "aneurisma" com apenas 24 anos), obra por outro lado gestada entre os meses de Março de 1866 e Agosto de 1867, e publicada em volume no ano da morte do autor, 1868 - materializa uma inalienável diferença. Num momento em que a narrativa "histórica" é hegemónica no panorama da prosa de ficção, num momento em que apenas se vislumbra a ficção de "actualidade", os Contos de Carvalhal objetivam uma escrita excepcional. Simões reconhece ares de família nos Contos Fantásticos de Teófilo Braga e nas Prosas Bárbaras de Eça de Queirós, volumes que reúnem contos praticamente coectâneos aos do autor de "Os canibais". Todavia, observa nestes últimos um lugar crítico no devir que conduz da ficção histórica à ficção de actualidade:

Os Contos de Álvaro do Carvalhal ocupam, contudo, na história da nossa ficção do século XIX um lugar inconfundível. Histórias fantásticas, histórias macabras, histórias de terror, histórias nem reais nem irreais, muito simplesmente suprarreais - que transcorrem num mundo que supera a realidade, ainda que real em si mesmo escritas durante a crise que afecta a ficção portuguesa no trânsito da novelística histórica para a novelística de actualidade, posteriores na data às de Teófilo [Braga] e às de Eça de Queirós, torna-se difícil dizer que devem ou não aos escritores que, entre nós, precederam o autor no cultivo desse novo género de ficção. (SIMÕES, 1987, p. 562)

O lugar inconfundível, segundo os termos de João Gaspar Simões, joga-se, por exemplo, nesta resistência dos contos de Carvalhal a uma filiação na contística de Teófilo e Eça. Mas não apenas, se bem que esta formulação, em si mesma, pode supor consequências importantes. Simões esforça-se, de forma constante, por concretizar uma excepcionalidade que, poderíamos dizer, se perfila como sendo algo inominável, ou apenas dita por muitos nomes imperfeitos. Vejamos. Em primeiro lugar, é sintomática a indecisão à hora de categorizar o genus a que pertencem as narrativas de Carvalhal. Simões chama-lhes "série de contos", se bem que sempre tem no seu horizonte interpretativo o facto de que Carvalhal lhes chamava "romances”. Simões, não aceitando esta classificação do autor, acrescenta que, por um critério de extensão, os relatos seriam antes "novelas" ${ }^{3}$. Em segundo lugar, Simões, ao propor uma filiação possível para o universo narrativo de Carvalhal, remete explicitamente para o "romance gótico", mas fá-lo não sem antes chamar a atenção para um suplemento que significaria um desenvolvimento próprio da ficção do autor dos Contos. Fá-lo, por outro lado, distinguindo "Os canibais", separando este conto do conjunto a que pertence. Das seis narrativas que integram os Contos, "Os canibais" supõe 
uma superação, uma transgressão mesmo, dentro de um conjunto de influxos que, contudo, animam a escrita. O seguinte parágrafo é fundamental, pois tenta justamente formular, uma vez mais, a singularidade de Carvalhal, uma singularidade que tem a sua melhor materialização justamente n' "Os canibais":

Nesse conto a imaginação macabra do jovem narrador alcança as suas notas mais estranhas. Influência do estilo tenebroso cultivado pelos mestres do "gothic romance" ou da "gothic novel", uma Anne Radcliffe ou um Horace Walpole? Talvez. E Carvalhal conhecia a primeira, pelo menos, autora do romance The Misteries of Udolpho, obra que cita num dos seus contos. Se não cita o segundo, alude aos mestres do fantástico em França e na Alemanha. Victor Hugo ou Balzac - o Balzac de Seraphite - são mencionados por Carvalhal. Também Hoffmann. E Edgar Poe, evidentemente. Em "Os canibais", contudo, Álvaro do Carvalhal excede-se e excede-os, a esses mestres, no sentido do macabro" (SIMÕES, 1987, p. 566, grifo meu).

Simões nomeia a diferença de Carvalhal como um "excesso" do "macabro". Não a "imaginação macabra” em si mesma, que aproxima Carvalhal de mestres como Radcliffe, Walpole, Hugo, Balzac, Hoffmann ou Poe. Trata-se, antes, de um excedente dessa imaginação, um mais além do macabro. Ora bem. O excesso macabro, fórmula proposta pela leitura de Simões, provém directamente da cena de canibalismo do conto. O argumento de Simões, efectivamente, depende desta cena. A tese de Simões responde à necessidade de ler o "acontecimento canibal", de ler a devoração do Visconde de Aveleda - protagonista do conto - pelo sogro e cunhados. Esta leitura, a leitura do "acontecimento canibal" por parte de Simões, é relativamente complexa.

Simões não concebe a imaginação do "acontecimento canibal", em primeiro lugar, como algo que possa provir de uma influência estritamente literária: "Associar tão terrível fantasia a uma influência simplesmente literária - a dos cultores da gothic novel - não basta para explicar o génio verdadeiramente singular de Álvaro do Carvalhal” (SIMÕES, 1987, p. 567). Existe algo, segundo Simões, que a imaginação do "acontecimento canibal" implica, que está para além do literário. Esse dehors texte é a própria vida de Álvaro do Carvalhal. É fundamental reter que a leitura do "acontecimento canibal" implica tanto o estético como o vital. O "macabro em excesso" recordo: o sintagma que nomeia a singularidade de Carvalhal segundo Simões - é o tropo em que se conjugam "vida" e "ficção". A cena canibal é, por outro lado, nova figura dessa nomeação. Mas, de que modo implica Simões a "vida" de Carvalhal nesta tropologia? Muito concretamente, a frase do crítico e historiador português em que o faz é a seguinte: "A sua condição de morto-vivo [i.e.: Álvaro do Carvalhal] - de estátua animada - muito terá contribuído, certamente, para o culto do terror que tão originalmente exercitou no seu extraordinário livro" (SIMÕES, 1987, pp. 567-568). Por 
outras palavras, a "vida" de Carvalhal convocada para a leitura do "macabro excesso" resume-se ao facto de que Álvaro do Carvalhal padecia uma doença terminal. Uma doença que determinava a sua escrita.

Não estranha esta ordem de argumentos de leitura num historiador e crítico como João Gaspar Simões, para quem a ponderação do biográfico na objectivação do gesto interpretativo não mereceria sequer discussão. Podemos observá-lo em toda a sua Perspectiva Histórica da Ficção Portuguesa, e em pormenor no capítulo dedicado a Carvalhal. Para Simões, neste sentido, Carvalhal é um narrador manqué na medida em que, tendo falecido aos 24 anos, não teria desenvolvido plenamente o seu "estilo" e, com ele, a sua competência narrativa: "Quem escrevia esses contos era demasiado jovem e a sua carreira viria a ser demasiado efémera para que algo importante se obtivesse do aparecimento quase insólito do seu génio narrativo" (SIMÕES, 1987, p. 562). Outros dois “excessos", pois, e intrinsecamente negativos: "demasiado" jovem e bio(biblio)grafia "demasiado" breve. Daí que a singularidade ficcional de Carvalhal, o seu "excesso macabro", seja acompanhada por uma defectiva competência como escritor. Neste sentido, a história biobibliográfica de Carvalhal não fazia mais do que reverberar uma história da ficção portuguesa que, nessas décadas centrais do século XIX, é ainda uma história incompleta. A "perspectiva" de João Gaspar Simões é teleológica: a ficção portuguesa consuma a sua plenitude - ou só se consuma tout court - com a obra de Eça de Queirós. A obra de Eça é o "fim" da ficção portuguesa a partir do qual Simões configura a sua genealogia da prosa literária do século XIX. O "romance contemporâneo" é esse "fim", e o "romance histórico" o antecedente que foi necessário superar para chegar até ele. Eis um dos diferentes lugares do texto de Simões em que se modula esta proposição: "Eça de Queirós conduziu o escritor português até ao romance, foi ele que lhe deu a chave de uma literatura de ficção emancipada da subjetividade romântica" (SIMÕES, 1987, p. 450; veja-se, também, a p. 455). Ou, então, "foi [Eça de Queirós], para todos os efeitos, que ensinou ao escritor nacional como se concebe e realiza uma técnica que, apesar de todos os seus formalismos discutíveis, ainda é a que mais se aproxima do tipo ideal de romance clássico" (SIMÕES, 1987, p. 456).

Simões encontra, assim, um problema no "estilo" defectivo de Carvalhal. Ou, melhor, Carvalhal instala-se no devir histórico da ficção do século XIX como um problema em que convergem o traço singular de um "excesso macabro" e um "estilo" manqué. Esta estilística de Carvalhal é objecto, neste sentido, de uma valoração aporética por parte de Simões. Por um lado, considera o seu estilo um estilo “obsoleto". O termo é seu, e exige algum esclarecimento. Simões refere-se, basicamente, a uma língua literária não coloquial, um uso, por conseguinte, a rebours da dicção do português literário de um Garrett ou de um Eça de Queirós. Neste sentido, Carvalhal aproximar-se-ia mais a modelos de língua literária como a de um António Feliciano de Castilho ou de um Camilo Castelo Branco. Língua literária "pré-moderna", com origem possível num mestre do século XVIII 
como Francisco Manuel do Nascimento (cf. SIMÕES, 1987, p. 568); língua literária, por outro lado, que no seu estrutural "esteticismo" antecipa muita da ficção finissecular e, inclusive, da ficção do século XX (cf. SIMÕES, 1987, p. 570).

Escrita obsoleta, pré-moderna ou esteticista, este é, sem dúvida, um dos tópicos mais recorrentes da escassa crítica sobre Álvaro do Carvalhal. Vejamos, com brevidade. Para José Simões Dias, o primeiro editor dos Contos, "o estilo não nos parece sempre igual, e em ocasiões encontramo-lo tão rebuscado que roça o ridículo" (apud SIMÕES, 1987, p. 568), e ainda “o abstruso era o seu ideal", acrescentando, enfim, que "Desejava parecer novo na forma, e tal novidade por vezes tornou-se tão obscura como fastidiosa" (SIMÕES, 1987, p. 569). Segundo José Régio, por seu turno, "Se as suas histórias já são monstruosas, a linguagem em que estão escritas sublinha ainda mais essa monstruosidade; é uma linguagem estirada ao máximo, procurando de tal forma produzir um efeito que pode produzir, chega a produzir, o efeito contrário: o de cair no grotesco, no burlesco, no ridículo" (apud OLIVEIRA, 1992, pp. 78-79). Para João Gaspar Simões, cuja leitura venho observando,

$\mathrm{O}$ uso de termos quase arcaicos, arcaicos em relação à linguagem oral que deve (ou deveria) ser a de um narrador, e o emprego de uma sintaxe áspera, mais de sermão que de ficção, contribuíam não pouco a acentuar a estranheza das suas histórias. Livrescas por condição, o livresco dos seus diálogos, da concepção das suas personagens, da montagem dos seus conflitos cairia em saco roto se o autor não se excedesse também em construções estilísticas livrescas e no emprego de termos ostensivamente obsoletos. (SIMÕES, 1987, p. 569)

Mais recentemente, Maria do Nascimento Oliveira volta a incidir sobre estes lugares num livro titulado O Fantástico nos Contos de Álvaro do Carvalhal. O seu argumento, de modo resumido, parte da conceptualização do fantástico levada a cabo por Tzvetan Todorov. Um argumento cujas principais figuras são as seguintes: o género define-se na construção de um enredo que solicita de um hipotético leitor a indecisão perante a naturalidade ou sobrenaturalidade de um acontecimento do universo narrativo. $\mathrm{O}$ fantástico supõe, pois, a irrupção, num mundo "verosímil”, de um ente ou facto que o leitor não consegue submeter a uma tradução que o racionalize. Diante deste quadro teórico, não estranha a "resistência" que Oliveira vai tendo que assinalar do conto "Os canibais". Culmina a sua leitura, justamente, considerando que o conto é, em suma, a subversão do "fantástico". Isto é, trata-se de uma leitura que convoca uma categoria - o "fantástico" - que não serve plenamente ao objecto cuja inteligência procura esclarecer. Ora bem. A derrogação do "fantástico", segundo Maria do Nascimento Oliveira, passa também pelo "estilo" de Carvalhal. Vejamos com atenção o seguinte parágrafo:

A audácia no uso de metáforas exacerbadas, as insólitas expressões sobreviventes de um romantismo oco e a correcção pomposamente erudita da frase não têm como fim 
neutralizar o cepticismo do leitor em relação a um género literário [i.e., o género "fantástico"] já de si suficientemente irracional. Efectivamente, a elegância obsoleta e retorcida do estilo de Carvalhal, o gosto por uma adjetivação rica e brilhante e uma linguagem rebuscada nos próprios diálogos impedem que nos instalemos e compartamos o medo ou a expectativa com as personagens. (OLIVEIRA, 1992, p. 80)

Os termos, se bem que modulados pela questão do fantástico, são os que a escassa tradição crítica tinha já enunciado. Oliveira, contudo, acrescentará uma reflexão: a de saber se o estilo de Carvalhal era produto da "imaturidade" do autor - que, neste sentido, teria processado, sem espírito crítico, a dicção "obsoleta" - ou se o estilo "obsoleto" era intencional no autor - que teria, assim, o propósito de criticar a persistência desse mesmo estilo nos finais da década de sessenta do século XIX. Esta questão é importante, e na verdade tinha aflorado em João Gaspar Simões, mas com evidentes diferenças e matizes. Para Simões, recordo, a questão dos textos de Carvalhal é a do "excesso macabro". Pois bem, o crítico considera, neste sentido, que a referida singularidade de Carvalhal se materializa justamente no seu peculiar estilo "obsoleto". Por outras palavras, o estilo obsoleto é correlato objectivo do excesso macabro, a singularidade dos contos de Carvalhal: "O nosso parecer é, por conseguinte, que optar por um vocabulário em desuso, por uma sintaxe oratória, por uma ênfase retórica, coisas que facilmente encontrava nos mestres do XVIII ou até no Castilho prosador, é a melhor forma de acentuar o insólito das suas histórias e de reforçar a singularidade irreal das suas fábulas" (SIMÕES, 1987, p. 569).

Há que dizê-lo claramente: a valoração do "estilo obsoleto" em Simões e em Oliveira serve propósitos divergentes, e quase poderíamos dizer que de sinal contrário. Para Simões o "estilo obsoleto" é o que objetiva o "excesso macabro", configurando-se nesta convergência a singularidade de Carvalhal. Para Oliveira, o "estilo obsoleto" é o que derroga, justamente, o que Simões chama "excesso macabro". Oliveira baseia a sua leitura na ideia de que em "Os canibais" o fantástico que deveria ser é subsumido pela derrisão do género em mãos de um "estilo obsoleto". Simões, por seu turno, preocupa-se por mostrar o "estilo obsoleto" como fenomenalização do "excesso macabro".

$\mathrm{Na}$ verdade, não são tão irreconciliáveis estes dois caminhos de leitura. De algum modo, a leitura de Oliveira potencia um argumento não desenvolvido por Simões. Efectivamente, para Simões o par "excesso macabro" /"estilo obsoleto" chega a poder ser pensado - ainda que, insisto, sem especial desenvolvimento por parte do crítico - sob a categoria do $h u$ mor. Não chega a fazer desse possível humorístico o modo que subsume a narrativa, como faz Oliveira.

Simões insinua o humor, muito concretamente, numa nova ponderação da cena canibal. Eis as suas palavras, depois de citar um parágrafo do banquete antropófago: 
Ocorre a cena no 'romance' em que a família de uma noiva, Margarida, devora, sem o saber, os restos calcinados de um noivo, que é visconde. A situação assume, desta forma, graças em parte à fraseologia não apenas literária mas também literariamente obsoleta do escrito, toda a sua singular irrealidade, todo o seu inverosímil tonus macabro, não sem algo de humorístico, de um humorismo conscientemente procurado. (SIMÕES, 1987, p. 570)

Uma vez mais, a cena fundamental é a que se refere ao "acontecimento canibal". De algum modo, a referida cena nem para Simões, nem para Oliveira, encaixa na leitura da narrativa ou, mais genericamente, na leitura dos Contos. Segundo Oliveira, a cena é justamente o momento em que se consuma a impossibilidade de pensar o fantástico em "Os canibais"4. Para Simões, recordo, essa cena não podia ser vinculada exclusivamente ao "literário", o seu carácter excessivo exigia a componente "biográfica" de Carvalhal. Paradoxalmente, o excesso que supõe a cena é fenomenalizado por uma dicção obsoleta ou, digamos, demasiado livresca. Um excesso de literatura a canibalizar a possibilidade de uma literatura nova: Carvalhal como 'Canibal Lector'.

O canibalismo de "Os canibais" representa o que vem sendo chamado canibalismo branco. Não se trata do canibalismo de um outro exótico, distante no espaço ou no tempo, que se quisesse bestializado. Ainda assim, nas suas entrelinhas, o conto vale-se dele. Em relação ao canibalismo concebido pela cultura colonial, trata-se ainda de um canibalismo muito peculiar: o canibal come o próximo, o familiar. É verdade que a ficção narrativa não nos propõe um canibalismo consciente. De facto, confronta-nos justamente com uma cegueira momentânea - que se não fosse ridícula seria uma cegueira trágica - que impede Urbano Solar e os seus dois filhos ser conscientes do acto antropofágico. Este desconhecimento não suspende, do meu ponto de vista, a valoração moral do acto antropofágico. O que sim faz é "estranhar" o ritual da comensalidade.

É muito interessante observar o modo como a crítica representa a cena do banquete. Simões, por exemplo, vê nela, já o disse, um "inverosímil tonus macabro". Mas, segundo penso, a ponderação da verosimilhança da devoração inconsciente não é tão unívoca. Na verdade, o que torna possível a cena é justamente que comam carne humana sem o saber. Sabendo-o, não o fariam; fazê-lo conscientemente sim seria inverosímil. Talvez seja este, por outro lado, o horror do representado: a possibilidade de já ter comido carne humana sem o saber.

Maria do Nascimento Oliveira, por seu turno, propõe-nos uma solução algo semelhante, se bem que com um pequeno e significativo suplemento. Também para Oliveira o banquete é o momento de maior afastamento do decorum narrativo. Recordemos que, dentro das determinações da sua leitura, isto significa que a cena não é consequente com os protocolos do género fantástico. A categoria do fantástico que se impõe com con- 
tumácia na leitura de Oliveira determina-lhe a necessidade de um mundo verosímil que acolha a irrupção de uma hipotética sobrenatureza. Carvalhal, neste sentido, desfiguraria irremediavelmente o género com esta cena:

Isso acontece especialmente na sequência que retrata a desarticulação, peça por peça, do visconde e na famosa cena de canibalismo em que o narrador, fazendo estremecer os nervos do seu leitor e sua credulidade, se compraz, com dilação, na matéria repugnante em que se transformou a sua personagem fantasma, chegando ao ponto de saborearthe o gosto. (OLIVEIRA, 1992, p. 77)

Preocupa a Oliveira, em primeira instância, o facto de o narrador saborear a carne. Claro está que não se trata de esquecer que o narrador é uma ficção do texto; trata-se de que, ao contrário das personagens Urbano Solar e seus filhos comendo o visconde, no narrador temos representada a "sensibilização" da carne saboreada. Efectivamente, Carvalhal rodeia a cena do banquete canibal de uma série de notas sensoriais. As personagens são instâncias sensíveis, representadas neste sentido pela sua corporalidade. É-nos dito, por exemplo, de Urbano Solar, no momento de entrar no quarto do Visconde e Margarida: "Entrou o bom homem despejando da garganta exclamações de pasmo, lançou a vista em roda e dilatou as cartilagens no nariz, tocado dum especial odor daquela atmosfera, que era um desespero para o ambicioso e faminto estômago de S. Ex. a" (CARVALHAL, 1990, p. 244).

Mas o momento culminante será, justamente, a forma como o narrador relata a degustação do "notável festim". Há que dizer que a descrição é escassa. O que efectivamente faz é representar o "sabor" da carne saboreada. Eis o parágrafo que, como víamos mais acima, tanto chama a atenção de Oliveira:

O sabor da carne não correspondia à aparência. Era excessivamente insulsa, viscosa e algo doce. Urbano Solar, desiludido, afirmava que apenas a sua experiência saberia descarnar os ossos convenientemente, assim como apenas o apetite saberia tolerar o dessaborido manjar (CARVALHAL, 1990, p. 246, grifo meu).

O texto sublinhado, de um ponto de vista narrativo, corresponde a um expediente conhecido: o narrador tem conhecimento do fluxo de consciência das personagens, e pode consequentemente representar as suas reacções à ingestão do alimento. É a isto a que Oliveira se refere quando afirma que o narrador chega ao ponto de saborear o gosto da carne.

O problema para Oliveira, ao considerar que este passo rompe definitivamente com a necessária verosimilhança do universo ficcional representado, estriba em que o sabor da carne humana é irrepresentável. Representar semelhante experiência sensível é, consequentemente, inverosímil. Mas creio que o que a cena nos solicita é algo muito diferente. Há que aceitar os termos da ficção que nos é proposta. Um facto determinante, 
neste sentido, é o da inconsciência de Urbano Solar e dos seus dois filhos de terem comido carne humana. Para eles é apenas carne assada. Digamos que é carne consumível, carne disponível para o consumo. Podemos supor que tão-pouco eles tenham comido carne humana antes de comer o visconde de Aveleda. Isto implica que não experimentam o acto antropofágico, inclusivamente de um ponto de vista estético, como a experiência de um sabor supostamente específico da carne "humana". Dizer da carne que é "insonsa", "viscosa" ou "um pouco doce" é descrever apenas uma carne comestível. Por outras palavras, poderíamos estar de acordo em que o consumo de carne humana por Urbano Solar e seus filhos seria inverosímil se fosse consciente. Mas não ao invés. Consumindo carne que nada mais é do que carne, permite conceber a enunciação de juízos estéticos sobre o objecto saboreado.

É também muito possível que Oliveira não remeta para o que na mencionada frase - "O sabor da carne não correspondia à sua aparência. Era excessivamente insulsa, viscosa e algo doce" - refira a sensibilidade de Urbano Solar e seus dois filhos. Dizia antes que estes enunciados são a representação que o narrador faz da experiência sensível das suas personagens. O que aqui se implica é que o narrador possa reconhecer essa experiência e narrá-la. Creio, de facto, que é também isso o que pretende significar Oliveira ao dizer que o narrador chega a saborear o gosto da carne. $\mathrm{O}$ narrador, neste sentido, não apenas provaria como poderia conceder uma inteligibilidade a essa degustação. Seria possível, neste sentido, conceber um narrador que, face a um acto canibal, dissesse coisas diferentes daquelas que efectivamente diz. Poderia dizer, por exemplo, que "os comensais degustaram a carne do visconde, uma carne de sabor indescritível”. Não poderia dizer, contudo, que "os comensais degustaram a carne do visconde, uma carne de sabor repugnante". Mesmo que introduzisse na descrição um juízo moral, continuaria a insinuar a possibilidade de saber qual é o sabor da carne humana. Mas há que insistir num aspecto. Resta-nos a possibilidade de que o narrador simplesmente se abstenha de valorar moralmente o acto canibal. E não porque não seja consciente de que a carne comida seja carne humana. Pelo contrário, suscita-se a possibilidade de que o que o narrador faz é não esquecer a ficção da inconsciência, por parte das personagens, de que a carne é humana.

Talvez a figura que vai sendo conformada seja, justamente, a que se joga na possibilidade de esquecer que a aquela carne é carne humana. Creio, ainda, que o conto conclui, precisamente, com semelhante esquecimento. O que me parece produtivo é, todavia, ponderar o modo como as leituras históricas (destaquei SIMÕES, 1987 e OLIVEIRA, 1992) do "acontecimento canibal", como lhe venho chamando, se sentem incómodas ao tentar integrar esse acontecimento nas suas leituras do conto e, mais amplamente, da escassa obra deixada por Álvaro do Carvalhal. Resumindo, direi que o que a narrativa nos propõe é, justamente, a possibilidade de descorporalizar totalmente a carne humana. O que comem Urbano Solar 
e os seus dois filhos não é carne de um corpo, é apenas carne, isto é, bem consumível. Muito provavelmente reside aqui o horror mais acabado: o de que a carne, inclusive a carne "humana", possa ser apenas carne para consumo. Um horror que se indistingue do ridículo.

O acontecimento canibal é a figuração aglutinadora de toda uma metaforologia da fome presente no conto "Os canibais" de Álvaro do Carvalhal. O estômago de Urbano Solar, pai de Margarida, é uma dessas figuras. Um estômago vazio, que há que encher, que há que alimentar. O horror que irrompe em todo momento na sociedade elegante é, justamente, o horror vacui: todos os indivíduos se sentem esfomeados, todos os indivíduos acabam enfrentando-se à consciência de que são alimento, de que são antropófagos e carne para devoração. Mas vejamos, em síntese, os diferentes tropos que nomeiam esta pulsão esfomeada.

Em primeiro lugar, o amor é figurado como uma paixão devoradora. De D. João diz-se que o seu "amor é como o dos tigres que, às vezes, se têm fome, devoram” (CARVALHAL, 1990, p. 226). Neste sentido, Margarida é a sua "apetitosa rês" (CARVALHAL, 1990, p. 231). Mas Margarida é também comedora, não apenas comida: "o visconde de Aveleda era amado com todo o faminto impulso de um seio virgem" (CARVALHAL, 1990, p. 231). D. João, por seu turno, não é apenas predador, é também presa: "D. João despediu um guincho de espanto como o do cerdo ao sentir-se nas garras do lobo" (CARVALHAL, 1990, p. 234). Enfim, o visconde de Aveleda antecipa uma viuvez para Margarida em que, voltando a ser presa, poderá ser uma "apetitosa rês" que escolhe o seu predador: "Deixar-te-ei viúva e virgem, e rica, muito rica. Das multidões que, famintas, se hão-de atropelar à entrada do teu palácio, podes eleger um esposo que te mereça" (CARVALHAL, 1990, p. 237).

Mas o que me parece mais significativo, e até agora não foi destacado pela crítica, é o facto de a metáfora canibal modular também a figura do narrador. Não apenas as personagens do conto são observadas em função do tropo antropofágico, o narrador é-o igualmente. A figuração do narrador, advirta-se, é complexa. É verdade que a contaminação pela imagem da devoração não esgota a ficção do narrador. Temos, por exemplo, a sugestão de um narrador como apontador de teatro. No início do capítulo VI, diz-nos a voz narrativa: "Agora que a minha autoridade de verdadeiro contra-regra de teatrinho aldeão chamou convenientemente a postos os esquisitos personagens, que hão-de figurar no presente capítulo, voltemos ao ponto em que deixei os suspirosos noivos na crítica posição de todos os noivos" (CARVALHAL, 1990, p. 235). Por outro lado, no início do conto, o protocolo narrativo recorre a um tópico bem conhecido, o do manuscrito encontrado de que o narrador seria legatário. Não há, verdadeiramente, a submissão do narrador a uma unidade ficcional.

Pois bem, a figura que acaba por objectivar o narrador é, insisto, a de um particular canibal. A ideia é a de que a montagem da sua histó- 
ria, a montagem da história que conta, obedece a um propósito devorador. Encena um mundo ficcional de modo a que possa, também ele, "comer". Leia-se o seguinte passo, que antecede o momento culminante do banquete canibal. O narrador fala de si próprio, um gesto que nos devolve uma cisão na voz narrativa (o narrador narra e narra-se narrando):

Depois acende um fogão monstro e de particular estrutura que estava preparado de encomenda para receber um homem inteiro, e lança-o, com bastante pena nossa, ao meio das chamas, e asa-o, não sei bem se com tenção de o comer. Palpita-me que o vai comer. Isto não se faz num país civilizado e liberal. (CARVALHAL, 1990, p. 242, grifo meu)

Para além de comedor, o narrador propõe-nos também uma autoimagem de doador de alimento comestível. Este ponto é muito importante. Ao contrário da leitura de Simões, o conto de Carvalhal, sim, tem uma moralidade. Efectivamente, toda a leitura do crítico se baseia na ideia de um universo ficcional não determinado por um suplemento moral. De facto, o mais importante do caso Álvaro do Carvalhal passa pelas questões morais que os seus relatos suscitam. Começando pelo primeiro editor, para quem "O livro de Álvaro é um escândalo no que se refere à moral" (apud SIMÕES, 1987, p. 566). Também António José Saraiva e Óscar Lopes colocam a questão de modo claro. Segundo estes dois críticos o caso Carvalhal devolve-nos

a mais típica manifestação portuguesa das intrigas melodramáticas de terror e violência, que rastreámos em Herculano, Camilo e Fialho, levados ao máximo de tensão contraditória entre o inverosímil pretensamente explicado, a tirada sentimental bastilhada da paródia, e uma permanente e ostensiva agressão à moral erótica mais conservadora, da qual contudo se apresenta como apologética" (SARAIVA e LOPES, 1996, p. 905, grifo meu)

Não se trata de que Simões não conceba uma necessária ponderação moral dos contos. Trata-se de considerar, como considera, que o "excesso macabro" o é porque tal macabro não é limitado por uma moralidade. É aqui, neste ponto, em que Simões convoca o facto empírico da iminente morte de Carvalhal - um Carvalhal consciente desse facto - para completar a sua leitura de "Os canibais". O jovem Carvalhal, face à certeza de que vai morrer, seria autor de ficções marcadas por tal certeza, o que significa, segundo Simões, que não teria travado a sua "imaginação macabra" com valores. A "amoralidade" seria, pois, um dos traços da arte de contar de Carvalhal. Amoralidade em "Honra Antiga" onde o narrador, assimilado ao próprio Álvaro do Carvalhal, discrimina "os pormenores da chacina, descreve a voluptuosidade do verdugo" (SIMÕES, 1987, p. 566). Amoralidade, ainda (e sobretudo), em "A Vestal" onde temos um caso de bestialismo entre um cão e uma jovem casada.

E, contudo, é o próprio narrador de "Os canibais" que diz explicitamente que doa, que oferece, que "dá" a moralidade da história que conta: "Mas, para que me não censurem por leigo na missão, que escolhi, aí a 
dou (a moralidade) em duas palavras suculentas, conceituosas e profundas como se me empertigasse sobre a sagrada trípode da sibila" (CARVALHAL, 1990, p. 247). Observe-se como as "duas palavras" são "suculentas", sugere-se que enunciar a moralidade é proporcionar um alimento, ou que a moralidade é como alimento que há que ingerir. E o alimento que regurgita para a mastigação leitora é a imemorial lição de que o homem é lobo do homem, e que a ficção de Carvalhal literaliza: "Quem sonhara, ao ver-te esplêndido, imponente e adorado, que cruel fim te reserva o avesso destino, sujeitando o teu requeimado tronco aos apetites vorazes de famintos canibais, que, ainda na véspera, te abraçavam no desafogo de uma amizade pura!" (CARVALHAL, 1990, p. 247). Uma vez mais, uma modulação do homo homini lupus.

Enfim, o conto conclui insistindo na replicação da figura canibal. O último andamento da fábula, como recordaremos, centra-se em Urbano Solar e nos dois filhos varões, um peralta e outro magistrado. Tendo descoberto a filha (e irmã) morta, sabedores já de terem comido carne assada do visconde de Aveleda, um dos filhos, o magistrado, comunica ao pai e ao irmão que são herdeiros da fortuna do visconde. A herança "salva-os". O narrador propõe então uma imagem final: "E encanzinaram-se no magistrado, como molossos esfaimados num couro rijo de pernil de Lamego" (CARVALHAL, 1990, p. 253). Se o narrador esvazia o valor da "amizade" na moralidade do seu relato, acaba a fazer o mesmo com a "família". Uma vez mais, o que temos é um universo apenas social. A sociedade elegante define-se como "classe" e como tal se distingue.

Pais que casam filhas, cavalheiros que caçam jovens donzelas, casamentos que não se consumam: o comunitário não se funda no "familiar". Não há instintos, apenas diferenciação classista agenciada pela impessoalidade do interesse ${ }^{5}$. Num mundo comodificado, no mundo do capital, o absoluto valor que é o capital faz perder ao indivíduo o preço que o indivíduo tem. O mundo comodificado não situa o indivíduo, muito necessitado este de proximidade, reserva de amor e amizade (cf. LUHMAN, 1982). Nem o amor, nem a amizade, nem a família, nem a literatura, são natureza. A fome que desfigura todas as personagens do conto tão-pouco. Uma fome natural seria o que naturalizaria um social classista. Se a fome canibal se repete é por ser esta a condenação social do homem. O que se pode dizer de outro modo: é também a História a que condena o homem.

Em última instância, o que "Os canibais" nos propõe é que é exactamente o canibalismo branco o que desumaniza o homem: enfim, que o demoniza. De facto, inclusive no quadro de uma ideologia ou invenção do selvagem, do primitivo, a outridade do canibal supõe, justamente, a sua "humanidade". De outro modo não se concebe o horror pelo canibalismo. Se o acto canibal de Urbano Solar e seus filhos é inumano é também basicamente humano. O único sujeito despossuído da sua humanidade, absolutamente desumanizado, é o visconde de Aveleda, coisificado, apenas carne comestível. 
Tudo isto, segundo creio, não é de somenos importância para a revisão das leituras críticas do conto. Por norma, são leituras que articulam fórmulas que obviam a comensalidade antropófaga. Ou melhor, são leituras que acomodam incomodamente a canibalização do Visconde de Aveleda. A fórmula mais explícita é a deslocação absoluta do lugar do conto. Encetemos e limitemos esta problemática remetendo para a seguinte asseveração: "E colocando a acção de Os Canibais no Japão, como [Álvaro do Carvalhal] coloca, respeita o que a ele mais convém: o exotismo do lugar, a irrealidade da cor local" (SIMÕES, 1987, p. 569). Recuperamos, ainda, a metáfora da cor, agora convocando o sintagma "cor local" que, assinale-se, é também funcional no conto. Por um lado, temos um narrador que manifesta "abstinência no emprego de cores locais" (CARVALHAL, 1990, p. 212). Por outro lado, é ainda o narrador que refere aquela "linguagem fantasiosa, que muitas vezes desdenha o presente para ir colorir-se nas eras aventurosas" (CARVALHAL, 1990, p. 216). 'Cor local', aqui, relaciona-se com a questão do realismo, com a questão da crónica de costumes. Mas, como podemos ler, a metáfora da cor é também usada para referir o discurso histórico ou historicizante. Assim, 'colorir' tanto pode ser tropo que representa a escrita do presente, como pode dizer uma escrita que o suspenda. Neste particular, o "narrador" opta pela "abstinência”. Considera ser a colocação de uma fábula num determinado "local" um imperativo da função narrativa. É uma necessidade reduzida a mínimos: o que acontece, acontece "em alguma parte" (CARVALHAL, 1990, p. 212). Perante o óbvio, não há como não evitar a "fidelidade”. É o óbvio, pois, que exime a narração de ser menos abstinente no emprego de "cores locais".

E, todavia, a abstinência não pressupõe um jejum tal que desvincule a ficção de correspondências várias com o "local" que a precede - correspondências naturais, precisamente por serem subsumidas pelo regime do 'óbvio'. O corpo social descrito é prioritariamente representado como comunidade de leitura que lê Dumas e Kock (cf. CARVALHAL, 1990, p. 213). Tal parâmetro poderia admitir a destopicalização, um algures que se pudesse dizer "Japão". Esta tradução perplexa cita, na verdade, o seguinte passo do relato: "Mal me serviria portanto o Japão. Filho da época, irei com ela. Fora mesmo atentado buscar modelo nos grotescos desasados do velho Portugal, quanto mais retroceder a ponto de me valer das roupagens cómicas dos Japoneses" (CARVALHAL, 1990, p. 212). O narrador, se algo faz, é negar o exótico espacial (Japão) e temporal (o velho Portugal) como mediadores da nomeação do lugar.

As já referidas leituras de Dumas e Kock, e muitas outras que reverberam no relato, assim como, destacadamente, bailes que, dir-se-ia nos jornais de meados do século, "são a estatística do mundo elegante" (cf. apud Mattoso, História de Portugal, vol. V, p. 526), são 'cor local' suficiente e absoluta. O baile é a expressão do todo social, que ali tem um dos seus rituais mais complexos. No relato, assim, o baile é a inscrição da exterioridade em que a instância de leitura revê a "realidade". O baile é in- 
dexável, pois, àquele mínimo de 'cor local' que absolutiza a necessidade de 'cor local'. Na sua acepção mais própria - a de "representação dos objetos com suas características exteriores, tais como a contextura, o volume, o peso, etc., procurando-se dar ao observador a ilusão de que se encontra, objetivamente, em face desta realidade"7 - o lugar tem a sua cor, o seu específico objectivado, "actual" e "costume", no baile. A descrição torna-se "ociosa" - pois, "Quem não sabe o que é um baile?" (CARVALHAL, 1990, p. 208) - sendo consequentemente reduzida ao "esboço" (CARVALHAL, 1990, p.208). Na acepção figurada, por conseguinte: "conjunto de traços característicos capazes de evocar um lugar, uma época (um relato cheiro de c. local)" ${ }^{8}$. Ou, também, "Conjunto de características exteriores que são típicas de coisas e de pessoas num dado espaço e num dado tempo. Dar cor local a uma descrição"."

Na verdade, o que o conto propõe é, num primeiro lance, delegar ao leitor a decisão de especificar o lugar ("Escolha o leitor a capricho o local da acção”, CARVALHAL, 1990, p. 208). Contudo, não deixa de imediatamente programar a especificação. O lugar deverá ser descrito com os seguintes atributos: leitura de "Dumas e Kock", supra citados, "seminário", "escândalos, "sotainas", a que acrescentará a seguinte didascália referencial: "Suponha o baile - se lhe apraz, mesmo por comodidade ou propriedade - suponha-o em Lisboa, na faustosa habitação de uma Ninon de Lenclos contemporânea" (CARVALHAL, 1990, p. 213). Entre os muitos lugares que podem ser, conquanto a especificação seja dada por leituras, esse lugar pode ser "Lisboa". Este é o nome, segundo creio, para um cronótopo: o Portugal "contemporâneo" justamente, isto é, um lugar de "tempos civilizados, tempos em que António José cedeu lugar à alta comédia, no período áureo da circunspecta casaca e do chapéu alto" (CARVALHAL, 1990, p. 212).

Propor à instância leitora que, nestes tempos "civilizados", se reconheça na figura do canibal é propor-lhe que se reveja na forma mais extrema de alteridade que terá podido conceber a sociedade oitocentista. A figura do canibal, neste sentido, introduz a possibilidade de desnaturalizar várias retóricas, ou a possibilidade de reconhecer que a sociedade se funda na retórica - isto é, nas "aparências". O Visconde de Aveleda ainda diz: "Eu ainda sou o mesmo que era" (CARVALHAL, 1990, p. 239). Quer isto dizer que é o representante - anacrónico, daí a condição de estátua - de uma sociedade como moral naturalizada. Para o Visconde há ainda um vício e uma virtude, valores discretos e discerníveis. Não cometeu qualquer crime, como protesta. Mas tão-pouco tem já meios para evitar que a autoimagem seja alvo de exclusão e vergonha. Toda a sua vida em sociedade se orienta por uma polidez que procura evitar embaraços. Daí, por exemplo, a excentricidade das luvas, as recitações de poesia, o discurso dos afectos com o género feminino. A identidade pessoal e a estrutura social têm o garante nestas retóricas. Ora, a introdução do tropo canibal temporaliza esta retórica esquecida de si na medida em que também um canibal a pode utilizar, nivelando-se por conseguinte vício e virtude, isto é, indistinguindo-se. 
Bailes, leituras e outros rituais, como a comensalidade, funcionam como símbolos participativos que reforçam a solidariedade social. $\mathrm{O}$ conto pedirá, enfim, que se subsumam todos ao tropo canibal. Rituais e símbolos pré-existem aos indivíduos e determinam-lhes os lugares que os despossuem de um específico. A insciência do acto canibal por parte de Urbano Solar e os filhos, a consciência anacrónica e a desmemória final perfazem o percurso do indivíduo em sociedade. A lição é material, pois, e entremeando tópica marxista, não é a consciência dos homens que determina o ser, mas o ser social que lhes determina a consciência. Se assim parece ser o caso, haverá que acrescentar que o que também se observa é uma cultura que não independe de uma condição social e material. E esta observância implicaria ainda - ponto interessante - que o conto não reduziria tal cultura a essas determinações; do que trataria, também, é de uma cultura que é esfera autónoma que se imiscui num processo histórico.

É neste quadro, enfim, que há que entender a anamorfose de um lugar irremediavelmente suposto. "Suponha", diz-nos o narrador, como líamos mais acima. Um espaço originário deslocado, ainda que reconhecido, tem as suas consequências. É um lugar suposto, parado, mal coagulado. Aquele 'supor', que o narrador pede como legiferador do nome do espaço, suga o tempo histórico, a possibilidade de um tempo histórico. O conto é "amador de sangue azul", não pode contar para além do logos desse amor. Note-se, pois, neste sentido, que no início e no fim do conto temos o mesmo omnívoro "sangue azul", não saímos dele absolutamente. Ou só o fazemos, como argumentarei, expropriando a legitimação moral que sustenta o sintagma. É verdade que "Os Canibais" nos contam algo como um processo histórico: grosso modo, o da aristocracia sendo 'devorada' pela burguesia. O tempo da "raça gótica" do par D. João/Visconde de Aveleda e o tempo adventício de Urbano Solar e os filhos, inaugurado pela violência canibal. Contudo, a mediação do protagonismo histórico do primeiro e do segundo par é feita pelo mesmo "sangue azul". Os parvenues são salvos, como seiva nova. A História gasta os indivíduos, suga-lhes a energia, petrifica-os. D. João é um fantasma, idem o Visconde de Aveleda. Urbano Solar e os filhos injectam o maquinismo de uma história que se sabe assentar na repetição do mesmo: a violência do homem pelo homem.

A questão está em compreender que o canibalismo, representado como acidente, isto é, como contingência absoluta, se perfila, em última instância, figuração de um universal social: o canibalismo é o peculiarmente humano de uma sociedade que se fundamenta na violência. $\mathrm{O}$ canibal é a iluminação final, a cor local (e universal). É a desfiguração, pois o canibal é também o canibalizado. Não só o Visconde da Aveleda é deglutido. Urbano Solar e os filhos, canibais, são também canibalizados pelo canibalismo. $\mathrm{O}$ final independe da afirmação de uma moralidade. Urbano Solar e os filhos vivem "através do ouro". Salvam-se - "Estamos salvos! Bendito sejas tu que nos salvaste!” (CARVALHAL, 1990, p. 253) - enquanto canibais. Há vida moral contrafeita depois do acto canibal. É verdade que se trata de um 
mundo pós-moral, pós-egótico, pelo menos no que toca à gramática egótica do mundo do Visconde de Aveleda/D. João. Lembremos que no momento em que tem lugar o reconhecimento da outridade do visconde, no momento da sua desmembração, da sua desumanização maquínica, da sua condição de estátua, temos também a afirmação da sua mesmidade egótica. É um momento que diríamos próprio do pathos ontológico romântico: "Eu sou ainda o mesmo que era" (CARVALHAL, 1990, p. 239). Este eu em posse de si próprio já só pode sê-lo como vítima numa História que o despossui de ser ego que se diz ego.

A cena final supõe a posteridade da idade do pai, pois supera a História como consecução linhagística sanguínea. Esta História é derrogada absolutamente na nupcialidade alienada. $O$ casamento não se consuma de modo a que a aliança que nele se objectivasse fizesse uma História como continuação da primogenitura. Como alguém dizia por aqueles idos, a aristocracia tem apenas um filho. D. João seria como um último desses filhos únicos. Ora, do que trata a cena final é de uma transmissibilidade de uma herança (o capital) que independe da sucessão sanguínea. A mobilidade do capital não obedece à razão de uma especificidade de sangue. Uma Modernidade do capital que, como virá a argumentar Simmel em Das Philosophie des geldes, produz comportamentos vitais (reificados) como a acumulação de capital e a práctica do consumo. O dinheiro, a fenomenologia do dinheiro que propõe, é o operador do trânsito da pré-Modernidade - com vínculos fortes, resumíveis na noção de gemeinschaft - à Modernidade, isto é, à gesellschaft, que liberta o indivíduo da dominação forte dos anteriores vínculos, mas que o perde como "pessoa" no mesmo lance. O indivíduo perde peculiaridade (em detrimento do pecúlio), por outras palavras, é assimilado à própria racionalidade e objectivação do dinheiro: "O dinheiro, cuja peculiaridade reside na ausência de peculiaridade” (SIMMEL, 1990, p. 470). Para Simmel, o dinheiro, essência da Modernidade, é esse inespecífico totalmente objectivado como absoluta mobilidade da troca (SIMMEL, 1990, p. 24). Neste processo que conduz da pré-Modernidade à Modernidade o dinheiro deveio, neste sentido, mais ele próprio. Propriedade que se baseia, na verdade, em ser ele extremo do impróprio: ela significa, precisamente, a "impessoalidade" Moderna. Vive-se pelo ouro, na fórmula que propõe "Os Canibais".

O capital move-se com plena autonomia, vitimando o mundo moral e social que o paternalizava. O final do conto mostra-nos que o monstro não era o Visconde de Aveleda. Os monstros são Urbano Solar e os seus filhos, monstros morais. Daqui, segundo creio - e entre outros aspectos -, advém da inadequação do conto em relação ao gótico. Os monstros triunfam, não são aniquilados como na tradição gótica. A cor, entretanto, interessa a este final, na medida em que se supõe um estado pós-egótico em que o regime sanguíneo é comutado pela mesmerização do ouro. O final é um estado de graça em que a outridade se veste com as cores do "sangue azul" sustentada por "milhões" herdados. Se antes, se no 
mundo moral do Visconde de Aveleda e D. João, a iluminação do rosto era dada pela coloração do sangue, a iluminação vitalista é, agora, agenciada pelo ouro.

Há que re-equacionar, por conseguinte, o final do conto, cruzando-o com a questão moral. Não se trata de uma moralidade 'positiva', é uma moralidade negativamente apresentada. Na destruição de uma estética que gerasse acordo - "a enorme fealdade do acontecimento" canibal é exactamente isso - Carvalhal propõe uma moralidade radical: o social é absolutamente irredimível, precisamente no momento irónico em que a "salvação" é anunciada. Que todo o social se funde sobre um acto de canibalismo significa que a perpetuação do social já só se faz em função da possibilidade da dissolução total das formas: a comensalidade antropófaga não se distingue da comensalidade civil. Não temos ainda em Carvalhal a confiança numa nova estética - como a naturalista - que unisse a esfera moral e artística dos indivíduos e das comunidades. A Carvalhal é possível uma revisão absolutamente última, i.e., escatológica, de uma existência co-extensiva à literatura. A literatura não ensina nada sobre a vida, apenas a deforma. Canibaliza-a, digamos. É a literalidade com que a sociedade "liberal" e "civilizada" se revê num "sangue azul" que nos devolve a sua barbárie (cf. ADORNO, 1970, p. 77). O “notável festim” de Urbano Solar e seus filhos propõe-nos que carne humana que se coma pode ser carne apenas: "O sabor da carne não correspondia à aparência. Era excessivamente insulsa, viscosa e adocicada. Urbano Solar, desiludido, afirmava que só a sua experiência saberia esburgar os ossos convenientemente, assim como só o apetite saberia tolerar o dissaborido manjar" (CARVALHAL, 1990, p. 246). Para uma comunidade de leitores que horroriza o canibalismo, ser canibal inadvertidamente será sem dúvida uma possibilidade inquietante.

A contumácia do fantasma do "sangue azul", numa sociedade burguesa que se imagina anacronicamente "raça gótica", é aproveitada pelo narrador d'”Os Canibais" para oficiar um exorcismo. Também ele é um gourmet de carne aristocrática: fagocita-a para regurgitá-la como alimento às suas leitoras (leitura feminina, sendo a mulher ainda algo como a janua diaboli). O conto, enfim, propõe uma alegoria da Historia, de uma História que se repete - tragicamente dirão alguns, já só como comédia, afirmarão outros -, mas aqui com uma muito peculiar modulação. É, como nos convida a considerar o narrador, um conto "amador de sangue azul; adora a aristocracia. E o leitor há-de peregrinar comigo pela alta sociedade; hei-de levá-lo a um ou dois bailes e despertar-lhe o interesse com os mistérios, amores e ciúmes dos que se armazenam por esses romances de armar ao efeito" (CARVALHAL, 1990, p. 208). O canibalismo é a monstruosidade moral - o âmago satánico - que organiza a vida social à custa dos sujeitos: o canibal como daemon e figura central do demos. Em suma: demos y daemon sem destrinça. Entretanto, da História 'faz-se crónica' em modo teratográfico, é coisa "gótica": engendrar, assim, o monstro que há que escrever e ler como quem come. A leitura e a tarefa do narrador como deglutição diabólica. 


\section{REFERÊNCIAS BIBLIOGRÁFICAS}

adorno, Theodor W. Asthetische Theorie. Frankfurt am Main: Surhkamp Verlag; ed. cit.: Teoria Estética. Trad. Artur Morão. Lisboa: Edições 70, 1970.

BAUDELAIRE, Charles. Du vin et du hashich, in Oeuvres completes. Vol. I. Paris: Ed. Claude Pichois/Bibliothèque de La Pléiade, 1975.

CARVALHAL, Álvaro do. Contos. Lisboa: Relógio d’Água, 1990.

DICIONÁRIO HOUAISS DA LÍNGUA PORTUGUESA. Rio de Janeiro: Editora Objetiva, 2001.

DICIONÁRIO DA LÍNGUA PORTUGUESA CONTEMPORÂNEA. Academia das Ciências de Lisboa. 2 vols. Lisboa: Verbo, 2001.

HAMILTON, Edith. A Mitologia. Tradução de Maria Luísa Pinheiro. Lisboa: D. Quixote, 1991.

LUHMANN, Niklas. Liebe als Passion. Frankfurt am Main: Surhkamp Verlag, 1982; ed. ut.: O Amor como Paixão. Para a Codificação da Intimidade. Tradução de Fernando Ribeiro. Lisboa: Difel, 1991.

MILLER, J. Hillis. Fiction and Repetition. Seven English Novels. Cambridge (Mass): HUP, 1982.

NOVO DICCIONÁRIO AURÉLIO DA LÍNGUA PORTUGUESA. 2. ed. Revista e ampliada. Rio de Janeiro: Editora Nova Fronteira, 1997.

OLIVEIRA, Maria do Nascimento. O Fantástico nos Contos de Álvaro do Carvalhal. Lisboa: Biblioteca Breve, 1992.

PRAZ, Mario. La carne, la muerte y el diablo en la literatura romântica. Trad. Rubén Mettini. Barcelona: Alcantilado, 1999.

PRICE, Merrall Llewelyn. Consuming Passions. The Uses of Cannibalism in Late Medieval and Early Modern Europe. New York \& London: Routledge, 2003.

RODRIGUES, E. “Ultra-Romantismo”. In Helena Carvalhão Buescu. Dicionário do Romanntismo Literário Português. Lisboa: Caminho, 1997, pp. 563-566.

SANTOS, M. P. Alves dos. "Carvalhal, Álvaro". In Helena Carvalhão Buescu. Dicionário do Romanntismo Literário Português. Lisboa: Caminho, 1997, pp. 76-77.

SARAIVA, António José \& Óscar Lopes. História da Literatura Portuguesa. $17^{\text {a }}$ ed. Porto: Porto Editora, 1996.

SIMMEL, Georg. Philosophy of Money. $2^{\text {nd }} \cdot$ ed. London: Routledge, 1990. 
SIMÕES, João Gaspar. Perspectiva Histórica da Ficção Portuguesa. 2a ed. Lisboa: D. Quixote, 1987.

SPIVAK, Gayatri Ch. "Can the Subaltern Speak?” (1988). In Diana Brydon, ed. Postcolonialism. Critical Concepts. Vol. IV. London and New York: Routledge, 2000.

(Recebido para publicação em 12/01/2012,

Aprovado em 31/01/2012)

\section{NOTAS}

1 A paginação consignada no ensaio corresponde a esta edição.

2 Lemos: "E misteriosa era a história da sua vida. Dos mil extravagantes boatos que corriam, como para lhe aumentar o prestígio, só se sabia ao certo que viera da América, e que era benquisto dos doutos e dos sensatos" (CARVALHAL, 1990, p. 211).

3 Simões formula o seguinte: “[Carvalhal ainda] revê os Contos até à página 270, segundo nos informa Simões Dias. Em previsão da muerte iminente, teria decidido reunir em livro a sua 'colecção de romances', como insistía em chamar às suas ficções - autênticas novelas - às quais acaba por conceder o título simples, pero pouco ou nada exacto, de Contos" (SIMÕES, 1987, pp. 564-565).

4 Oliveira altera completamente as categorias que utilizara para a leitura do resto do conto: fala, agora, de "dimensão satírica", "pura alegoria" ou "grotesco" (OLIVEIRA, 1992, pp. 82-83).

5 Spivak, lendo Marx, recorda como a história da identidade por interesse é indiferente aos indivíduos: "Marx contention here is that the descriptive definition of a class can be a differential one - its cutting off and difference from all other classes: 'in so far as millions of families live under economic conditions of existence that cut off their mode of life, their interest, and their formation from those of the other classes and place them in inimical confrontation, they form a class. There is here no such thing as a 'class instinct' at work here. In fact, the collectivity of familial existence, which might be considered the arena of 'instinct', is discontinuous with, though operated by, the differential isolation of classes [...] the formation of a class is artificial and economic, and the economic agency or interest is impersonal because it is systematic and heterogeneous." (SPIVAK, 1988, p. 1433).

6 Leia-se, a este respeito, a seguinte reflexão: "At the same time as the allegation of cannibalism functions to divest the accused of their humanity, however, it invariably and ironically also functions to reaffirm it, since membership in the human species is a prerequisite for the eater of human flesh to be considered a cannibal. At one level, the accusation, then, will always fail, collapsing under the weight of its own logical contradictions, although in the case of the New World, it would not do so before fixing the European image of the Americas for centuries to come" (PRICE, 2003, p. 84).

7 Cf. Aurélio, s.u. cor, p. 475, col. 3, “cor local”, acepções 1 e 2.

8 Cf. Houaiss, s.u. cor, p. 833, col. 1.

9 Dicionário da Língua Portuguesa Contemporânea, s.u. cor, p. 971, col. 1. 